DR. ENQING HOU (Orcid ID : 0000-0003-4864-2347)

DR. GUOYI ZHOU (Orcid ID : 0000-0002-5667-7411)

Article type : Primary Research Articles

\title{
Effects of climate on soil phosphorus cycle and availability in natural
}

\section{terrestrial ecosystems}

Enqing Hou ${ }^{1,3,6^{*}}$, Chengrong $\mathrm{Chen}^{2}$, Yiqi Luo ${ }^{3}$, Guoyi Zhou ${ }^{1,6}$, Yuanwen Kuang ${ }^{1,6}$, Yuguang Zhang ${ }^{4}$, Marijke Heenan ${ }^{5}$, Xiankai Lu ${ }^{1,6}$, Dazhi Wen ${ }^{1,6, *}$

${ }^{1}$ Key Laboratory of Vegetation Restoration and Management of Degraded Ecosystems, South China Botanical Garden, Chinese Academy of Sciences, Guangzhou 510650, China.

${ }^{2}$ Griffith School of Environment, Griffith University, Nathan, Qld 4111, Australia.

${ }^{3}$ Center for Ecosystem Science and Society, Northern Arizona University, Flagstaff, Arizona 86011, USA.

${ }^{4}$ Institute of Forestry Ecology, Environment and Protection, and the Key Laboratory of Forest Ecology and Environment of State Forestry Administration, Chinese Academy of Forestry, Beijing, 100091, China.

${ }^{5}$ Department of Science, Information Technology and Innovation, Queensland Government, Dutton Park, Brisbane, Qld 4102, Australia.

${ }^{6}$ Guangdong Provincial Key Laboratory of Applied Botany, South China Botanical Garden, Chinese Academy of Sciences, Guangzhou 510650, China.

* Corresponding author: houeq@scbg.ac.cn (EH); dzwen@scbg.ac.cn (DW)

Running head: Climatic effects on soil phosphorus

This article has been accepted for publication and undergone full peer review but has not been through the copyediting, typesetting, pagination and proofreading process, which may lead to differences between this version and the Version of Record. Please cite this article as doi: $10.1111 /$ gcb.14093

This article is protected by copyright. All rights reserved. 
Paper type: Primary Research Article

Abstract Climate is predicted to change over the 21 st century. However, little is known about how climate change can affect soil phosphorus (P) cycle and availability in global terrestrial ecosystems, where $\mathrm{P}$ is a key limiting nutrient. With a global database of Hedley $\mathrm{P}$ fractions and key associated physiochemical properties of 760 (semi-natural) natural soils compiled from 96 published studies, this study evaluated how climate pattern affected soil P cycle and availability in global terrestrial ecosystems. Overall, soil available P, indexed by Hedley labile inorganic P fraction, significantly decreased with increasing mean annual temperature (MAT) and precipitation (MAP). Hypothesis-oriented path model analysis suggests that MAT negatively affected soil available P mainly by decreasing soil organic P and primary mineral $\mathrm{P}$ and increasing soil sand content. MAP negatively affected soil available $\mathrm{P}$ both directly and indirectly through decreasing soil primary mineral $\mathrm{P}$; however, these negative effects were offset by the positive effects of MAP on soil organic P and fine soil particles, resulting in a relatively minor total MAP effect on soil available P. As aridity degree was mainly determined by MAP, aridity also had a relatively minor total effect on soil available $\mathrm{P}$. These global patterns generally hold true irrespective of soil depth $(\leq 10 \mathrm{~cm}$ or $>$ $10 \mathrm{~cm})$ or site aridity index $(\leq 1.0$ or $>1.0)$, and were also true for the low-sand $(\leq 50 \%)$ soils. In contrast, available P of the high-sand ( $>50 \%)$ soils was positively affected by MAT and aridity and negatively affected by MAP. Our results suggest that temperature and precipitation have contrasting effects on soil $\mathrm{P}$ availability and can interact with soil particle size to control soil P availability.

Keywords: Soil phosphorus availability, climate, phosphorus cycle, soil property, global pattern

This article is protected by copyright. All rights reserved. 


\section{Introduction}

Over the 21 st century, both global mean temperature and precipitation are projected to rise, with substantial spatial variation (Stocker et al., 2014). Some places (e.g. the Mediterranean) will be drier while others (e.g. Northern Hemisphere high latitudes) will be wetter, with a general global trend towards drying (Cook et al., 2014). The ongoing climate change may have large effects on nutrient cycles and availability in terrestrial ecosystems (Delgado-Baquerizo et al., 2013), with potentially strong feedbacks to the global climate systems and ecosystem functions (e.g. soil carbon sequestration) (Wang et al., 2010). While considerable attention has been paid to the responses of carbon $(\mathrm{C})$ and nitrogen $(\mathrm{N})$ cycles to altered climate regimes (Stocker et al., 2014), much less has been known about the responses of phosphorus (P) cycles and availability (Reed et al., 2015, Stocker et al., 2014). Given the worldwide P limitation in terrestrial ecosystems (Augusto et al., 2017), improved understanding of how climate change affects soil P cycle and availability is urgently needed to aid the incorporation of $\mathrm{P}$ cycle into earth system models (Reed et al., 2015).

Phosphorus in soil exists in a variety of forms that differ in their availability to plants (Cross \& Schlesinger, 1995; Yang \& Post, 2011). Soil P that is readily available to plants (i.e. available P) always represents a small but variable fraction (typically $<5 \%$ ) of soil total $\mathrm{P}$, whereas the majority of $\mathrm{P}$ in soil is not readily available and associated with soil primary minerals (defined as primary mineral P), secondary minerals (secondary mineral P), or organic constituents (organic P), or occluded by soil minerals (occluded P) (Condron \& Newman, 2011, Frossard et al., 2000, Hedley et al., 1982, Hou et al., 2016, Tiessen \& Moir, 2007). These soil constituents-associated P pools are not readily available to plants but regulate soil $\mathrm{P}$ availability over years or longer time scales by biological and geochemical processes (Frossard et al., 2000, Hou et al., 2016, Vitousek et al., 2010). Further, these $\mathrm{P}$ pools differ in their contributions to soil $\mathrm{P}$ availability due to their chemical and biological This article is protected by copyright. All rights reserved. 
nature (Hou et al., 2016; Yang \& Post, 2011). Biological processes (i.e., immobilization/mineralization) control the transformation between soil available $\mathrm{P}$ and organic P (Harrison, 1987). Geochemical processes include weathering, adsorption/desorption, precipitation/dissolution, and solid-phase transformations (e.g. solidphase diffusion) (Barrow, 1983, Frossard et al., 2000, Tiessen et al., 1984). Weathering controls the transformation of soil primary mineral $\mathrm{P}$ to other soil $\mathrm{P}$ pools including soil available P (Walker \& Syers, 1976). Adsorption/desorption and precipitation/dissolution control the transformation between soil available $\mathrm{P}$ and secondary mineral P (Frossard et al., 2000). Solid-phase transformations control the transformation between soil secondary mineral P and occluded P (Barrow, 1983).

Climate (i.e. temperature, precipitation, and aridity) can potentially affect soil $\mathrm{P}$ availability through a variety of direct and indirect processes. For example, precipitation can directly drive soil P leaching (Sims et al., 1998), while temperature can directly enhance soil P sorption and desorption (Barrow, 1983). Climate can also affect soil P availability through three groups of factors including (1) soil P forms, (2) key soil properties such as soil particle size, $\mathrm{pH}$, and organic matter content, and (3) plant and soil microbial activities (e.g. P uptake and return), with the first group of factors additionally affected by the other two groups of factors. For example, high temperature facilitates the transformation of available $\mathrm{P}$ and secondary mineral P to occluded P in soil (Barrow, 1983, Siebers et al., 2017), whereas high precipitation may drive the loss of secondary mineral $\mathrm{P}$ or even occluded $\mathrm{P}$ in very humid environments (annual precipitation $>2000 \mathrm{~mm}$ ) (Austin \& Vitousek, 1998). Both high precipitation and high temperature facilitate rapid immobilization, mineralization, and weathering through direct effect or indirect effects on key soil properties and plants and soil microbial activities, causing changes to soil $\mathrm{P}$ forms and availability (Delgado-Baquerizo et al., 2013, Dixon et al., 2016, Siebers et al., 2017, Vitousek et al., 2010). Increase in aridity

This article is protected by copyright. All rights reserved. 
may decrease plant cover and thus increase the risk of wind-driven loss of fine soil particles (Delgado-Baquerizo et al., 2013) that contain higher P content and P sorption capacity than the coarse soil particles (Ohalloran et al., 1987). These multiple direct and indirect effects add together as the total (or net) effect of climate on soil $\mathrm{P}$ availability.

Given the complex effects of climate on soil P availability, inconsistent relationships between climate and soil total or available $\mathrm{P}$ concentration have been reported at local to regional scales (Austin \& Vitousek, 1998, Jiao et al., 2016, Miller et al., 2001, Tian et al., 2010; Vitousek \& Chadwick, 2013; Zhang et al., 2005). Previous studies have also explored empirical relationships between climate and soil total $\mathrm{P}$ (Yuan et al., 2017) and organic $\mathrm{P}$ (Harrison, 1987) concentrations at a global scale. However, no study has systematically examined the relationships between climate and soil $\mathrm{P}$ forms and availability or quantitatively partitioned the various direct and indirect effects of climate on soil P availability at a global scale. Such quantitative analysis can provide deep insights into mechanisms underpinning climate effects on soil $\mathrm{P}$ availability. This is critical for the reliable prediction of soil $\mathrm{P}$ availability under global climate changes using process-based earth system models.

In this study, we applied a hypothesis-oriented path model analysis to a global database including sequentially extracted soil P fractions, climatic variables, and key soil properties. Combining path model analysis and the global database, we can quantify the relative importance of potential direct and indirect pathways and soil properties in mediating climate effect on soil $\mathrm{P}$ availability at a global scale. Specifically, we aimed to address the following questions: 1) How are climate factors (temperature, precipitation, and aridity degree) related to soil $\mathrm{P}$ availability at a global scale?, and 2) How do soil P forms and key soil properties mediate climate effects on soil P availability?

This article is protected by copyright. All rights reserved. 


\section{Materials and methods}

\section{Data sources, data structure, and data preparation}

This study compiled a database of soil P fractions by surveying the peer-reviewed, published research that used the sequential fractionation technique developed by Hedley et al. (1982) and modified by Tiessen \& Moir (1993) (Fig. S1). This fractionation technique has been the most commonly used procedure for the sequential fractionation of $\mathrm{P}$ in soils (Condron \& Newman, 2011). Our survey was restricted to studies of unfertilized, uncultivated, and (semi-natural) natural soils. This study defined (semi-natural) natural soils as those in sites with primary vegetation or with a stand age higher than 10 years for forests. All data were collected at the plot scale. For data with replicates in the same plots, the average values per plot were calculated and used. Detailed information about the collection of Hedley P fractions was described in our previous study (Hou et al., 2016).

Our previous database included information on Hedley P fractions, soil total P, soil type, soil depth, vegetation type, and site geographic location (latitude and longitude) from a total of 626 soil samples in 85 studies published before August 2015 (Hou et al., 2016). With the database, our previous study tested hypothetical soil P transformation models and quantified the importance of different soil $\mathrm{P}$ pools and $\mathrm{P}$ transformation pathways in shaping soil $\mathrm{P}$ availability at a global scale (Hou et al., 2016). In this study, the database was updated to include 802 soil samples in 98 studies using the same literature survey method as described previously and included papers published as recently as April 2017. Moreover, the present study added information on site climate conditions (mean annual temperature (MAT), mean annual precipitation (MAP), and aridity degree), soil particle size measurements (sand (0.05$2.00 \mathrm{~mm})$, silt $(0.002-0.05 \mathrm{~mm})$ and clay $(<0.002 \mathrm{~mm})$ contents $)$, three key soil chemical properties ( $\mathrm{pH}$ in water, total organic $\mathrm{C}$ and total $\mathrm{N}$ ), and parent material type to the updated 
database. Only data of the mineral soil samples (760 samples in 96 studies) were used for the present study. Our updated database also included parameters such as site slope, soil age, forest stand age, and oxalate-extractable soil $\mathrm{Fe}$ and $\mathrm{Al}$ concentrations. These parameters were, however, not used in the present study due to their insignificant to weakly significant relationships with soil $\mathrm{P}$ measures and the large proportions (81-94\%) of missing data (Table S1). The spatial distribution of the 760 soil samples is shown in Fig. 1.

Soil P fractions extracted by the procedures of Hedley et al. (1982) and Tiessen \& Moir (1993) were assigned into five functional P pools including soil available P, secondary mineral P, organic P, primary mineral P and occluded P (Fig. S1), based on their functional roles and chemical nature and as defined by our previous study (Hou et al., 2016) and other studies (Cross \& Schlesinger, 1995). For example, soil inorganic P (Pi) fractions extracted by resin and $0.5 \mathrm{M} \mathrm{NaHCO}_{3}(\mathrm{pH} 8.5)$ are always closely correlated (Hou et al., 2016) and both can be readily available to plants (Tiessen \& Moir, 2007), therefore these two Pi fractions were summed up as a surrogate of soil available P.

For the 760 soil samples, in cases where the referenced studies did not report the latitude or longitude of the measurement, the approximate latitude and longitude (for 80 samples) were derived by geocoding the name of the location in Google Earth 7.0 (the free version). In cases where the referenced studies did not report MAT (351 samples), MAP (299 samples), or altitude (427 samples), the values were derived from WorldClim (Hijmans et al., 2005) using site geographic location (latitude and longitude). A test of relationships between data of climate and altitude reported in literature and those derived from WorldClim (MAT: $r=0.95$, $P<0.001, \mathrm{n}=407$; MAP: $\mathrm{r}=0.85, P<0.001, \mathrm{n}=459$; altitude: $\mathrm{r}=0.88, P<0.001, \mathrm{n}=328)$ indicates that the derived data from WorldClim were generally reliable for our study sites.

This article is protected by copyright. All rights reserved. 
Aridity index (AI) of each site was obtained from CGIAR-CSI using data from WorldClim (Trabucco \& Zomer, 2009). The AI value decreases as aridity increases. MAT of our study sites ranged from -5 to $29{ }^{\circ} \mathrm{C}$, MAP ranged from 31 to $6000 \mathrm{~mm} \mathrm{yr}^{-1}$, and the AI value ranged from 0.03 to 3.92 (Table 1$)$.

In our database, forest was the major vegetation type (63.7\%), followed by grass (18.4\%) and shrub (6.4\%), with relatively small proportions for other vegetation (e.g. savanna) (Fig. S2a). Soils covered all the major soil types classified according to the U.S. Department of Agriculture soil classification system (Soil Survey Staff, 1999) except Gelisols (Fig. S2b). Soil depth ranges were recoded into an average value (Fig. S2c); for example, "0$15 \mathrm{~cm}$ depth" was recorded as "7.5 cm depth". Parent materials were grouped generally according to Porder \& Ramachandran (2013) (Fig. S2d). The exceptions were glacial till and volcanic ash, which were named as per the referenced studies (e.g. Levy \& Schlesinger, 1985). A total of 390 samples had at least one measurement of soil particle size (i.e. soil sand, silt, or clay content), of which 114 samples were measured by pipette method (Carter \& Gregorich, 2007), 71 samples by hydrometer method (Carter \& Gregorich, 2007), and 13 samples by other methods (e.g. using a laser diffraction particle size analyzer), while the method of measurement was not indicated for other samples (192). Soil $\mathrm{pH}$ in water was measured using a soil: water (w:v) ratio mostly between 2.5 and 10 . Soil total P concentration was determined either separately or calculated as a sum of Hedley P fractions using colorimetric analysis, soil organic $\mathrm{C}$ concentration was measured by dichromate-acid digestion, and soil total $\mathrm{N}$ concentration was measured by the Kjeldahl method (Carter \& Gregorich, 2007).

Among the 760 samples, values for fractioned soil $\mathrm{P}$ pools were missing for $7.0-17.8 \%$ of the samples, soil $\mathrm{pH}$ for $23.9 \%$, soil organic $\mathrm{C}$ for $17.4 \%$, and soil particle size for $49.2-$ $56.3 \%$ (Table 1). For these soil properties, data were missing either because the values were This article is protected by copyright. All rights reserved. 
not indicated or because the measurement method did not fulfill our survey requirements. Our previous study suggests that including samples with missing values of Hedley P fractions does not significantly bias multivariate relationships among soil $\mathrm{P}$ fractions in our database (Hou et al., 2016).

\section{Statistical analysis}

The distribution of all variables were examined. For variables that were highly skewed (skewness $>1.0$; Table 1 ), $\log _{10}$ transformation was performed to improve normality before relationship analyses, such as altitude, soil depth, soil total organic $\mathrm{C}$, total $\mathrm{N}$, total $\mathrm{P}$ and all fractioned soil P pools. Bivariate relationships between selected climate and soil properties were explored with Pearson's correlation method using SPSS 19.0 (SPSS Inc., Chicago, IL, USA) and with plot technique and regression method using SigmaPlot 12.0 (Systat Software, San Jose, CA, USA). Partial correlation analyses were performed using SPSS 19.0 to determine the degree at which MAT affects the correlations between MAP and soil P pools, or vice versa, to explore the interrelations between MAT, MAP, and soil P pools. Structural equation modeling (SEM) (Grace, 2006) was adopted to quantify the relative importance of potential direct and indirect pathways and soil properties in mediating climate effect on soil available P. Boosted regression tree (BRT) analysis (Elith et al., 2008) was performed to quantify the influences of climate factors on soil P pools relative to other selected key ecosystem properties.

Three data manipulations were made before the multivariate (i.e. SEM and BRT) analyses. (1) The high correlation between soil organic $\mathrm{C}$ and total $\mathrm{N}$ concentrations $(\mathrm{r}=$ $0.96, P<0.001, \mathrm{n}=460)$ made it difficult to do multivariate analysis by colinearity. Only soil organic $\mathrm{C}$ concentration was adopted as an indicator of soil organic matter content. (2) Given

This article is protected by copyright. All rights reserved. 
the redundancy of soil sand, silt, and clay contents in describing soil particle size and the generally stronger relationships of soil sand content with soil P fractions than soil silt and clay contents (Table S2), only soil sand content was adopted. (3) The relationships of MAP and AI with soil P pools were mostly better depicted by exponential models than by linear models (Fig. 2). Therefore, $\log _{10}$ transformed MAP was used. To facilitate the interpretation of our results, [maximum $\log _{10}$ transformed AI in the data set (i.e. 0.593$)-\log _{10}$ transformed $\mathrm{AI}]$ was used as a surrogate of aridity degree. This index increases with decreasing $\log _{10} \mathrm{MAP}$ $(\mathrm{r}=-0.83, P<0.001, \mathrm{n}=758)$. For SEM analyses, two additional data manipulations were made. One was several variables (e.g. soil available P) showed a curvilinear relationship with latitude, i.e., sites closer to the equator tended to be different from sites farther from the Equator. This was handled by using the absolute value of latitude to substitute latitude (Delgado-Baquerizo et al., 2013). The other was missing values of parameters were filled by pooling estimates from five datasets imputed by predictive mean matching method based on the collected data. This was performed using multiple imputation as implemented in the package 'mice' (version 2.30) (Buuren \& Groothuis-Oudshoorn, 2011) in R 3.3.3 (R core team, 2017). The estimated values had generally comparable distribution patterns with the collected values in our database (Fig. S3).

After data manipulations were complete, an a-priori model was established (Fig. S4) based on known or hypothetical effects and relationships among climate, soil P dynamics, and key associated soil properties. This model included the five fractioned soil P pools, climate (MAT and MAP, and aridity), soil $\mathrm{pH}$, organic $\mathrm{C}$, and sand content. Moreover, the model accounted for the spatial structure (latitude, longitude, altitude, and soil depth) of the selected climate and/or soil properties. However, the model did not include types of vegetation, soil, and parent materials, because these ecosystem properties affect soil $\mathrm{P}$ availability mainly through their effects on key soil properties and soil $\mathrm{P}$ forms, but do not

This article is protected by copyright. All rights reserved. 
directly mediate climate effect on soil P availability. Moreover, including these categorical variables would make the model very complicated. In general, our a-priori model hypothesized that climate can affect soil available $\mathrm{P}$ both directly and through its effects on soil P forms and key soil properties (Fig. 3a). Given the dependence of AI (i.e. MAP/annual potential evapotranspiration ratio; Trabucco and Zomer (2009)) on MAP, the effect of aridity on soil available P was analyzed separately from the effects of MAP and MAT, i.e. one model depicts the effects of MAP and MAT on soil available P and another model depicts the effect of aridity on soil available P. Detailed justification of the a-priori model is described in Text S1. The a-priori model was parameterized using both the global database with all samples and sub-databases with the AI value $\leq 1.0$ or $>1.0$, soil sand content $\leq 50 \%$ or $>$ $50 \%$, or soil depth $\leq 10 \mathrm{~cm}$ or $>10 \mathrm{~cm}$. The SEM analyses with sub-databases were performed to test whether climate effects on soil P forms and availability vary with site conditions. A good model fit was indicated by $0.05 \leq P \leq 1.00$, and $0 \leq \mathrm{RMSEA} \leq 0.05$ (RMSEA is the root mean square error of approximation) (Grace, 2006). Our a-priori model attained a generally satisfied overall fit to both the global database and the sub-databases (Table S3).

We calculated the standardized total effects of climate and soil properties on the fractioned soil P pools, to show the relative effects of climate and soil properties on soil P forms and availability. We also calculated the standardized effects of climate on soil available $\mathrm{P}$ in different pathways (i.e. via soil $\mathrm{P}$ forms, via soil properties, and directly), to show the relative importance of different pathways in mediating climate effect on soil P availability. All SEM analyses were conducted using AMOS 21.0 (SPSS Inc., Chicago, IL, USA).

For BRT analyses, the predictors were climate factors (i.e. MAT and MAP), types of vegetation, soil, and parent materials, and three key soil physiochemical properties (organic $\mathrm{C}$ and sand contents and $\mathrm{pH}$ ), while the response variables were the five soil P pools. Since AI This article is protected by copyright. All rights reserved. 
was a function of MAT and MAP (Trabucco \& Zomer, 2009), AI was not included in the BRT analyses. For each response variable, a BRT model was constructed using the recommended parameter values: learning rate $(0.01)$, bag fraction $(0.75)$, cross validation (10), and tree complexity (2, which indicates the level of interactions in BRT) (Elith et al., 2008). Because the predicted variables are continuous numerical variables, a Gaussian distribution of errors was employed for all BRT fittings. The relative importance of each predictor represented a percentage of the total variations where the model accounted for dependent variables. All BRT analyses were performed with the gbm package version 2.1.1 (Ridgeway, 2015) plus custom code of Elith et al. (2008) in R version 3.3.3.

\section{Results}

\section{Bivariate relationships}

With the increase in MAT, all soil P pools other than secondary mineral P (i.e. available $\mathrm{P}$, primary mineral $\mathrm{P}$, organic $\mathrm{P}$, occluded $\mathrm{P}$, and total $\mathrm{P})$ linearly decreased $\left(\mathrm{R}^{2}=0.01-0.29\right.$; $P<0.01$; Fig. 2). Soil secondary mineral $\mathrm{P}$ was not significantly related to MAT $(P>0.05$; Fig. 2j). After partial correlation with MAP as the control variable, all significant relationships $(P<0.05)$ between MAT and soil P pools sustained (Table S4). With the increase in MAP, soil primary mineral $\mathrm{P}$ exponentially decreased $\left(\mathrm{R}^{2}=0.32, P<0.001\right.$; Fig. 2e), while the opposite is true for soil organic $\mathrm{P}$, secondary mineral $\mathrm{P}$, and occluded $\mathrm{P}\left(\mathrm{R}^{2}=\right.$ 0.09-0.24, $P<0.001$; Fig. 2h, k, and n). Soil available $\mathrm{P}$ and total $\mathrm{P}$ both linearly decreased with the increase in MAP $\left(\mathrm{R}^{2}=0.07\right.$ and 0.04 , respectively, $P<0.001$; Fig. $2 \mathrm{~b}$ and $\left.\mathrm{q}\right)$. However, after partial correlation with MAT as the control variable, the relationship between MAP and soil total $\mathrm{P}$ became positive $(\mathrm{r}=0.09, P=0.04)$, and the relationship between MAP and soil available $\mathrm{P}$ became insignificant $(\mathrm{r}=0.03, P=0.47)$ (Table $\mathrm{S} 4)$. The AI value was 
related to soil P pools generally in the same manner as MAP (Fig. 2), except that the relationship between $\mathrm{AI}$ and soil total $\mathrm{P}$ was not statistically significant $(P=0.93)$.

All soil $\mathrm{P}$ pools other than primary mineral $\mathrm{P}$ (i.e. available $\mathrm{P}$, organic $\mathrm{P}$, secondary mineral $\mathrm{P}$, occluded $\mathrm{P}$, and total $\mathrm{P})$ linearly decreased with increasing soil sand content $\left(\mathrm{R}^{2}=\right.$ $0.05-0.32 ; P<0.001 ;$ Fig. S5) while they linearly increased with increasing soil organic C concentration $\left(\mathrm{R}^{2}=0.09-0.54, P<0.001\right.$; Fig. S5). With the decrease in soil $\mathrm{pH}$, soil primary mineral $\mathrm{P}$ and total $\mathrm{P}$ decreased while soil organic $\mathrm{P}$, secondary mineral $\mathrm{P}$, and occluded $\mathrm{P}$ increased $\left(\mathrm{R}^{2}=0.05-0.45, P<0.001\right.$; Fig. S5).

Overall climate effects on soil P pools

The SEM analysis with MAT and MAP on all samples explained $44 \%, 59 \%, 61 \%$, and $52 \%$, respectively, of the variations in soil available $\mathrm{P}$, primary mineral $\mathrm{P}$, organic $\mathrm{P}$, and secondary mineral P (Fig. 3b). Among soil P pools, soil organic P and primary mineral P had the strongest positive effects on soil available $\mathrm{P}(\beta=0.27$ and 0.25 , respectively), followed by soil secondary mineral $\mathrm{P}(\beta=0.11)$, with no direct effect from soil occluded $\mathrm{P}$. Soil $\mathrm{pH}$ positively affected soil primary mineral $\mathrm{P}$ and negatively affected soil secondary mineral $\mathrm{P}$ (Figs. 3b and 4). Soil organic $\mathrm{C}$ positively affected soil organic $\mathrm{P}$ and also positively affected soil secondary mineral $\mathrm{P}$, primary mineral $\mathrm{P}$ and available $\mathrm{P}$ (Figs. $3 \mathrm{~b}$ and 4). Soil sand content negatively affected all soil P pools and soil organic C (Figs. 3b and 4).

MAT negatively affected all soil $\mathrm{P}$ pools and soil organic $\mathrm{C}$ by a positive effect on soil sand content (Fig. 3b). Moreover, MAT had a direct negative effect on soil primary mineral P and a direct positive effect on soil secondary mineral P (Fig. 3b). MAT negatively affected soil available $\mathrm{P}$ both directly and indirectly through decreasing organic $\mathrm{C}$, organic $\mathrm{P}$, and 
primary mineral P and increasing soil sand content (Fig. 3b), though the direct effect was not statistically significant $(\beta=-0.11, P=0.18)$. MAT had a positive but relatively small effect on soil available $\mathrm{P}$ via soil secondary mineral $\mathrm{P}(\beta=0.58 \times 0.11=0.06)$. Consequently, MAT had a total negative effect on soil available $\mathrm{P}(\beta=0.35$; Fig. 4).

In contrast to MAT, MAP positively affected all soil $\mathrm{P}$ pools and soil organic $\mathrm{C}$ via a decrease in soil sand content (Fig. 3b). MAP negatively affected soil primary mineral P both directly and indirectly by decreasing soil $\mathrm{pH}$ (Fig. 3b). MAP positively affected soil organic $\mathrm{P}$ mainly through its effect on soil organic $\mathrm{C}$ and positively affected soil secondary mineral $\mathrm{P}$ through all three soil properties (i.e. soil $\mathrm{pH}$, organic $\mathrm{C}$, and sand content) (Fig. 3b). MAP negatively affected soil available $\mathrm{P}$ both directly and indirectly through decreasing soil $\mathrm{pH}$ and primary mineral P. Meanwhile, MAP positively affected soil available P via soil sand content, organic C, organic P, and secondary mineral P (Fig. 3b). Since the negative effects of MAP on soil available $\mathrm{P}$ were generally counteracted by the positive effects, MAP had a minor total effect on soil available $\mathrm{P}(\beta<0.01$; Fig. 4$)$.

The SEM analysis with aridity on all samples explained $46 \%$ of the variation in soil available P (Fig. 3c). The effects of aridity on all soil properties including soil available P were generally opposite to those of MAP, i.e. positive effects on soil sand content, $\mathrm{pH}$, and primary mineral $\mathrm{P}$ and negative effects on soil organic $\mathrm{C}$, organic $\mathrm{P}$, and secondary mineral $\mathrm{P}$ (Figs. 3c and 4).

This article is protected by copyright. All rights reserved. 
Climate effects on soil P pools under different site conditions

The SEM analysis with MAT and MAP on sub-databases showed that the total effect of MAT on soil available $\mathrm{P}$ was consistently negative in both the arid $(\mathrm{AI} \leq 1.0)$ and the nonarid (>1.0) environments, for both the topsoils (soil depth $\leq 10 \mathrm{~cm}$ ) and the subsoils $(>10$ $\mathrm{cm})$, and also holds for the low-sand $(\leq 50 \%)$ soils, with a relatively larger total effect on soil available $\mathrm{P}$ in the non-arid than the arid environments and for the topsoils than for the subsoils (Fig. 5). In contrast, total effect of MAT on available P of the high-sand ( $>50 \%)$ soils was positive $(\beta=0.43$; Fig. 5), which results from both a direct positive effect $(\beta=0.28)$ and positive effects via organic $\mathrm{P}$ and secondary mineral P (Figs. S7 and S8).

The total effect of MAP on soil available $\mathrm{P}$ was minor, irrespective of climate regime or soil depth and also holds for the low-sand soils (Fig. 5), though effects of MAP on all other soil P pools and soil properties were generally larger in the arid than the non-arid environments and for the topsoils than for the subsoils (Fig. S8). In contrast, the total effect of MAP on available $\mathrm{P}$ of the high-sand soils was negative $(\beta=-0.40$; Fig. 5$)$, mainly resulting from a direct negative effect $(\beta=-0.39$; Fig. S7e). The effects of aridity on all soil properties including soil available P were generally opposite to those of MAP (Figs. 5, S7 and S8).

\section{The influences of climate factors on soil P pools relative to other ecosystem properties}

BRT analyses with selected climate, vegetation, soil, and parent material factors as predictors explained $82 \%-91 \%$ of the variations in soil P pools (Table 2). In general, proportions of the total explained variations in soil $\mathrm{P}$ pools accounted for by climate factors (i.e. MAT and MAP) were comparable to those accounted for by soil type, parent material 
type, and soil $\mathrm{pH}$, and organic $\mathrm{C}$ and sand contents, and higher than those accounted for by vegetation type (Table 2). Specifically, soil organic C accounted for the largest proportion of the total explained variation in soil available P (22.5\%), followed by MAT (16.5\%), MAP (16.1\%), parent material type (14.6\%), soil type (13.3\%), $\mathrm{pH}(14.6 \%)$ and sand content (3.9\%), and vegetation type $(2.0 \%)$. Among selected predictors, soil organic $\mathrm{C}$ had a major influence on soil organic P (53.3\%); MAT, soil type, and soil $\mathrm{pH}$ had the largest influences on soil primary mineral $\mathrm{P}(29.7 \%, 25.8$, and $23.8 \%$, respectively); soil $\mathrm{pH}$ had the largest influence on soil secondary mineral P (22.6\%); soil properties including soil type, $\mathrm{pH}$, organic $\mathrm{C}$ concentration, and sand content had the largest influences on soil occluded $\mathrm{P}$ (sum of $69 \%$; Table 2).

\section{Discussion}

With a global database of Hedley P fractions, climate, and key associated soil properties, this study evaluated for the first time, to our knowledge, how climate pattern affected soil P cycle and availability at a global scale. Our findings suggest that MAT, MAP, and aridity all affected soil P cycle and availability in global terrestrial ecosystems, with the effects varying essentially with soil particle size. Since soil organic $\mathrm{P}$ and primary mineral $\mathrm{P}$ were the major soil P pools contributing to soil available P (Fig. 3b and c; Hou et al. 2016), climate affected soil available $\mathrm{P}$ largely through their effects on soil organic $\mathrm{P}$ and primary mineral $\mathrm{P}$.

This article is protected by copyright. All rights reserved. 
Contrasting effects of MAT and MAP on soil P cycle and availability

Soil P availability has been widely viewed to be lower in hot and wet tropical regions than in cold temperate regions (Harrison, 1987, Zhang et al., 2005). Consistent with this hypothesis, soil available P significantly decreased with rises in MAT and MAP at the global scale (Fig. 2a and b). The effects of MAT and MAP on soil P availability have, however, often not been well separated, due to the typically spatial autocorrelation of MAT and MAP (Harrison, 1987, Vitousek \& Chadwick, 2013). By applying hypothesis-oriented multivariate analyses, our results demonstrated that MAT, but not MAP, negatively affected soil P availability at the global scale (Fig. 4 and Table S4). This finding was consistent with the finding from a recent study on native grassland soils in North America (Siebers et al., 2017). Our results further revealed that the contrasting effects of MAT and MAP on soil P availability was mainly due to the opposite effects of MAT and MAP on soil organic P, which can be further attributable to their opposite effects on soil organic $\mathrm{C}$ and particle size (Fig. 3b). These results suggest that biological P cycle and soil particle size mediated the contrasting effects of MAT and MAP on soil P availability in global terrestrial ecosystems.

Previous studies suggest that MAT can negatively affect soil P availability by increasing soil weathered extent and plant P uptake (e.g. Dixon et al., 2016, Unger et al., 2010). Consistent with these studies, MAT negatively affected soil available P both directly and indirectly through decreasing soil primary mineral $\mathrm{P}$, though the direct effect was not statistically significant (Fig. 3b). MAT negatively affected soil available P also by decreasing soil organic $\mathrm{P}$ and organic $\mathrm{C}$ and increasing soil sand content (Fig. 3b). A negative effect of MAT on soil organic $\mathrm{C}$ has been reported by previous studies at both global and regional scales (Jobbágy \& Jackson, 2000, Yuan et al., 2017), probably explained by a greater response of decomposition to temperature relative to plant production (Jobbágy \& Jackson, 2000). Since soil organic P pool was predominantly and positively controlled by soil organic This article is protected by copyright. All rights reserved. 
matter content (Fig. 3b), MAT negatively affected soil organic P. This result suggests that soil $\mathrm{P}$ mineralization is generally more sensitive to temperature change than plant $\mathrm{P}$ production. The negative effect of MAT on soil available P through increasing soil sand content occurred, likely because high MAT increases the risk of wind-driven loss of Penriched fine soil particles (Delgado-Baquerizo et al., 2013, Ohalloran et al., 1987). Although MAT positively affected soil available $\mathrm{P}$ by increasing soil secondary mineral $\mathrm{P}$, this effect was much smaller than the negative effects discussed above. Consequently, MAT had a total negative effect on soil available $\mathrm{P}$ at the global scale. The total negative effect of MAT on soil available $\mathrm{P}$ indicates that the extent of $\mathrm{P}$ limitation on terrestrial primary productivity will increase under ongoing global warming, as predicted by earth system models that incorporate the terrestrial P cycle (Sun et al., 2017, Wang et al., 2010).

Interestingly, a negligible total effect of MAP on soil available P was mainly due to counteraction of its direct negative effect on soil available $\mathrm{P}$ and its negative effect on soil primary mineral $\mathrm{P}$ versus its positive effects on soil organic $\mathrm{P}$ and organic matter contents, rather than lack of effect. It has long been recognized that MAP can negatively affect soil P availability by driving $\mathrm{P}$ loss and plant $\mathrm{P}$ uptake and enhancing soil weathered extent (Austin \& Vitousek, 1998, Vitousek et al., 2010, Walker \& Syers, 1976). However, positive effects of MAP on soil P availability have been less frequently reported (Miller et al., 2001, Siebers et $a l ., 2017)$. Indeed, plant production is generally more sensitive to MAP than decomposition (Jobbágy \& Jackson, 2000), therefore soil organic matter content and thus soil organic P pool may increase with MAP (Jobbágy \& Jackson, 2000, Miller et al., 2001). MAP positively affected soil available $\mathrm{P}$ also by decreasing soil sand content, probably explained by the decreasing risk of wind-driven loss of P-enriched fine soil particles with increasing MAP (Delgado-Baquerizo et al., 2013, Ohalloran et al., 1987). These findings pointed out the This article is protected by copyright. All rights reserved. 
importance of biological P cycle and soil fine particles in offsetting the negative effects of MAP on soil available $\mathrm{P}$ and primary mineral $\mathrm{P}$.

Since aridity degree was mainly determined by MAP, aridity also had a minor total effect on soil $\mathrm{P}$ availability. Nevertheless, it is clear that increase in aridity can be caused by either a decrease in MAP or an increase in MAT, or both. Contrasting effects of MAP and MAT on soil P availability revealed in this study suggests that the effect of aridity on soil P availability depends on the driver of aridity. If an increase in aridity is caused by an increase in MAT, aridity will negatively affect soil $\mathrm{P}$ availability; meanwhile if it is caused by a decrease in MAP, aridity will have a relatively minor effect on soil $\mathrm{P}$ availability. This result highlights the importance of distinguishing the drivers of aridity when studying aridity effect on soil $\mathrm{P}$ availability (Delgado-Baquerizo et al., 2013, Jiao et al., 2016).

\section{Climate effects on soil P cycle and availability under different site conditions}

The patterns of climate effects on soil P forms and availability revealed at the global scale were generally true for both the topsoils and the subsoils and in both the arid and the non-arid environments, although the climate effects were mostly larger for the topsoils than for the subsoils and in the arid environments than in the non-arid environments. The relatively larger climate effects on topsoil properties than on subsoil properties is expected, because climate effect on soil property is a top-down process (Jobbágy \& Jackson, 2000). It is also expected that climate effects on soil properties were generally larger in the arid environments than in the non-arid environments. This is because soil water supply, which can be altered by climate changes, plays a more important role in determining ecosystem properties in arid environments than in non-arid environments (Delgado-Baquerizo et al., 2013).

This article is protected by copyright. All rights reserved. 
Climate effects on soil available P were, however, contrasting between the low-sand soils and the high-sand soils. This result indicates that climate can interact with soil particle size to affect soil P availability. High-sand soils are more prone to loss of nutrients including P via leaching and runoff compared to low-sand soils when experiencing high amounts of precipitation (Sims et al., 1998). Therefore, MAP may significantly and negatively affect the available $\mathrm{P}$ of high-sand soils but not of low-sand soils. This finding implies that the ongoing global alteration of annual precipitation will significantly affect soil $\mathrm{P}$ supply in terrestrial ecosystems with high-sand soils. In addition to the amount, the intensity of precipitation also tends to change (i.e. increase) over the $21^{\text {st }}$ century globally (Stocker et al., 2014). Increase in precipitation associated with an increase in precipitation intensity will likely have a greater impact on runoff and erosion than simply an increase in precipitation amount (Nearing et al., 2005). Therefore, the ongoing global precipitation change may have a stronger negative effect on high-sand soil available $\mathrm{P}$ than demonstrated here based only on the amount of precipitation.

Like MAP, MAT also interacted with soil particle size to affect soil available P. Several processes probably underpin this interaction. Firstly, increase in temperature likely reduces the moisture content of a high-sand soil but may have a relatively minor effect on that of a low-sand soil (Fernandez-Illescas et al., 2001, He et al., 2014). Decrease in soil moisture content caused by an increase in temperature may offset the positive effect of temperature on plant growth and $\mathrm{P}$ uptake (Barber et al., 2000). Therefore, the available $\mathrm{P}$ of high-sand soils may be less depleted by temperature-driven plant growth than that of low-sand soils. Secondly, high-sand soils have lower ability of protecting phosphatase enzymes from degradation, which is temperature sensitive, relative to low-sand soils (Allison, 2006). Therefore, MAT may affect the geochemical mineralization of organic P differently in highsand soils and in low-sand soils. Finally, high-sand soils and low-sand soils differ in the 
intensities of $\mathrm{P}$ sorption and desorption (Ohalloran et al., 1987), both of which are temperature-sensitive processes (Barrow, 1983). If the balance between P sorption and desorption is changed by temperature differently for soils with different particle size, MAT effect on soil available P may differ between high-sand soils and low-sand soils. However, little is known about how temperature and soil particle size may interactively affect soil $\mathrm{P}$ availability, which warrants further study.

Climate can potentially affect a number of $\mathrm{P}$ cycles in terrestrial ecosystems, as discussed above. However, it remains unclear the importance of climate factors in determining soil $\mathrm{P}$ availability, relative to plant characteristics and other environmental conditions such as vegetation, soil and parent material types. Our results revealed that the proportions of variation in soil available P explained by climate factors (MAT and MAP) were generally comparable to those explained by soil type, $\mathrm{pH}$, and organic $\mathrm{C}$ concentration, and parent material type, at the global scale. This result confirms the notion that climate is a major driver of soil P availability at large spatial (i.e. global and regional) scales (Harrison, 1987, Zhang et al., 2005). It calls for the necessity of incorporating soil $\mathrm{P}$ cycle and availability into earth system models, to better predict how climate change will affect the key functions and processes of terrestrial ecosystems (Reed et al., 2015).

Some uncertainties are associated with our data and assessment approach, but such uncertainties are not likely to change our main results. Firstly, uncertainty may be associated with the imperfect separation of functional soil P pools by the Hedley P procedure (Condron \& Newman, 2011). Theoretically sound paths among climate, soil properties, and soil P pools in this study, however, suggests that this uncertainty may not significantly change our model structure. Secondly, a large proportion of missing data for soil sand content may cause an uncertainty with the paths between soil sand content and other variables in our model but does not change the total effects of climate on soil available P. Likewise, a lack of This article is protected by copyright. All rights reserved. 
measurements of soil P loss, plant P uptake and production, and soil microbial activity make it difficult to separate their mediations in climate effect on soil $\mathrm{P}$ availability. Thirdly, our SEM model did not consider the potential interactions of MAP and MAT. Dissimilar climate effects on soil P forms and availability between the arid and the non-arid environments implies that MAT may interact with MAP in affecting soil P cycle and availability, which warrant future studies to specifically target the interactions with novel approaches.

In summary, MAT negatively affected soil P availability, mainly by decreasing soil primary mineral $\mathrm{P}$ and organic $\mathrm{P}$ pools and increasing soil sand content. MAP was also negatively related to soil $\mathrm{P}$ availability, but this was essentially due to the spatial autocorrelation of MAP and MAT. A minor total effect of MAP on soil P availability primarily resulted from counteraction of its direct negative effect on soil available $\mathrm{P}$ and its negative effect on soil primary mineral $\mathrm{P}$ versus its positive effect on soil organic $\mathrm{P}$ and its effect on soil particle size. Since aridity degree was mainly determined by MAP, aridity also had a minor total effect on soil available P. These global patterns generally hold true irrespective of soil depth or site aridity index, and were also true for the low-sand soils. An exception is that $\mathrm{P}$ availability of the high-sand soils was positively affected by MAT and aridity and negatively affected by MAP. These findings suggest that climate effects on soil P availability largely depend on the responses of biological $\mathrm{P}$ cycle and soil particle size.

Global warming and alteration of precipitation amount have contrasting effects on soil $\mathrm{P}$ availability. The effect of aridity on soil P availability depends on the driver of aridity (change in temperature, precipitation, or both). Our findings have important implications for climate-smart soil conservation and management and can aid the incorporation of soil $\mathrm{P}$ dynamics into earth system models.

This article is protected by copyright. All rights reserved. 
Acknowledgements This study was supported by the National Natural Science Foundation of China (41401326; 41771522; 31570483) and South China Botanical Garden Fund (Y561021001). The authors state no conflict of interest. The dataset and reference list are available at https://doi.org/10.1594/PANGAEA.883611.

\section{References}

Allison SD (2006) Soil minerals and humic acids alter enzyme stability: implications for ecosystem processes. Biogeochemistry, 81, 361-373.

Augusto L, Achat DL, Jonard M, Vidal D, Ringeval B (2017) Soil parent material- a major driver of plant nutrient limitations in terrestrial ecosystems. Global Change Biology, 23, 3808-3824.

Austin AT, Vitousek PM (1998) Nutrient dynamics on a precipitation gradient in Hawai'i. Oecologia, 113, 519-529.

Barber VA, Juday GP, Finney BP (2000) Reduced growth of Alaskan white spruce in the twentieth century from temperature-induced drought stress. Nature, 405, 668-673.

Barrow N (1983) A mechanistic model for describing the sorption and desorption of phosphate by soil. Journal of Soil Science, 34, 733-750.

Buuren S, Groothuis-Oudshoorn K (2011) mice: Multivariate imputation by chained equations in R. Journal of Statistical Software, 45, 1-67.

Carter MR, Greogorich EG (2007) Soil Sampling and Methods of Analysis (Second Edition), CRC Press.

This article is protected by copyright. All rights reserved. 
Condron LM, Newman S (2011) Revisiting the fundamentals of phosphorus fractionation of sediments and soils. Journal of Soils and Sediments, 11, 830-840.

Cook BI, Smerdon JE, Seager R, Coats S (2014) Global warming and 21st century drying. Climate Dynamics, 43, 2607-2627.

Cross AF, Schlesinger WH (1995) A literature review and evaluation of the Hedley fractionation - Applications to the biogeochemical cycle of soil phosphorus in natural ecosystems. Geoderma, 64, 197-214.

Delgado-Baquerizo M, Maestre FT, Gallardo A et al. (2013) Decoupling of soil nutrient cycles as a function of aridity in global drylands. Nature, 502, 672-676.

Dixon JL, Chadwick OA, Vitousek PM (2016) Climate- driven thresholds for chemical weathering in postglacial soils of New Zealand. Journal of Geophysical Research: Earth Surface, 121, 1619-1634.

Elith J, Leathwick JR, Hastie T (2008) A working guide to boosted regression trees. Journal of Animal Ecology, 77, 802-813.

Fernandez-Illescas CP, Porporato A, Laio F, Rodriguez-Iturbe I (2001) The ecohydrological role of soil texture in a water-limited ecosystem. Water Resources Research, 37, 2863-2872.

Frossard E, Condron LM, Oberson A, Sinaj S, Fardeau JC (2000) Processes governing phosphorus availability in temperate soils. Journal of Environmental Quality, 29, 1523.

Grace JB (2006) Structural Equation Modeling and Natural Systems, Cambridge University Press.

This article is protected by copyright. All rights reserved. 
Harrison AF (1987) Soil Organic Phosphorus: A Review of World Literature, Commonwealth Agricultural Bureaux International.

He Y, Hou L, Wang H, Hu K, Mcconkey B (2014) A modelling approach to evaluate the long-term effect of soil texture on spring wheat productivity under a rain-fed condition. Scientific Reports, 4, 5736.

Hedley M, Stewart J, Chauhan B (1982) Changes in inorganic and organic soil phosphorus fractions induced by cultivation practices and by laboratory incubations. Soil Science Society of America Journal, 46, 970-976.

Hijmans RJ, Cameron SE, Parra JL, Jones PG, Jarvis A (2005) Very high resolution interpolated climate surfaces for global land areas. International Journal of Climatology, 25, 1965-1978.

Hou E, Chen C, Kuang Y, Zhang Y, Heenan M, Wen D (2016) A structural equation model analysis of phosphorus transformations in global unfertilized and uncultivated soils. Global Biogeochemical Cycles, 30, 1300-1309.

Jiao F, Shi X, Han F, Yuan Z (2016) Increasing aridity, temperature and soil pH induce soil CNP imbalance in grasslands. Scientific Reports, 6, 19601.

Jobbágy EG, Jackson RB (2000) The vertical distribution of soil organic carbon and its relation to climate and vegetation. Ecological Applications, 10, 423-436.

Levy ET, Schlesinger WH (1999) A comparison of fractionation methods for forms of phosphorus in soils. Biogeochemistry, 47, 25-38.

Miller AJ, Schuur EaG, Chadwick OA (2001) Redox control of phosphorus pools in Hawaiian montane forest soils. Geoderma, 102, 219-237.

This article is protected by copyright. All rights reserved. 
Nearing M, Jetten V, Baffaut C et al. (2005) Modeling response of soil erosion and runoff to changes in precipitation and cover. Catena, 61, 131-154.

Ohalloran IP, Stewart JWB, Kachanoski RG (1987) Influence of texture and management practices on the forms and distribution of soil phosphorus. Canadian Journal of Soil Science, 67, 147-163.

Porder S, Ramachandran S (2013) The phosphorus concentration of common rocks-a potential driver of ecosystem P status. Plant and Soil, 367, 41-55.

R Core Team (2017) R: A language and environment for statistical computing. $R$ Foundation for Statistical Computing, Vienna, Austria.

Reed SC, Yang X, Thornton PE (2015) Incorporating phosphorus cycling into global modeling efforts: a worthwhile, tractable endeavor. New Phytologist, 208, 324-329.

Ridgeway G (2015) gbm: Generalized Boosted Regression Models. R package version 2.1.1.

Siebers N, Sumann M, Kaiser K, Amelung W (2017) Climatic effects on phosphorus fractions of native and cultivated north American grassland soils. Soil Science Society of America Journal, 81, 299-309.

Sims JT, Simard RR, Joern BC (1998) Phosphorus Loss in Agricultural Drainage: Historical Perspective and Current Research. Journal of Environmental Quality, 27, 277-293.

Soil Survey Staff(1999) Soil Taxonomy: A Basic System of Soil Classification for Making and Interpreting Soil Surveys, Natural Resources Conservation Service. U.S. Department of Agriculture Handbook 436.

This article is protected by copyright. All rights reserved. 
Stocker TF, Qin D, Plattner GK et al. (2014) Climate change 2013: the physical science basis: Working Group I contribution to the Fifth assessment report of the Intergovernmental Panel on Climate Change, Cambridge University Press.

Sun Y, Peng S, Goll DS et al. (2017) Diagnosing phosphorus limitations in natural terrestrial ecosystems in carbon cycle models. Earth's Future, 5, 730-749.

Tian H, Chen G, Zhang C, Melillo JM, Hall CA (2010) Pattern and variation of C: N: P ratios in China's soils: a synthesis of observational data. Biogeochemistry, 98, 139-151.

Tiessen H, Moir J (1993) Characterization of available P by sequential extraction. In: Soil Sampling and Methods of Analysis (eds Carter MR) Lewis Publishers, Ann Arbor.

Tiessen H, Moir JO (2007) Characterization of available P by sequential extraction. In: Soil Sampling and Methods of Analysis, Second Edition. (eds Carter MR, Gregorich EG). CRC Press, Boca Raton, FL.

Tiessen H, Stewart J, Cole C (1984) Pathways of phosphorus transformations in soils of differing pedogenesis. Soil Science Society of America Journal, 48, 853-858.

Trabucco A, Zomer R (2009) Global aridity index (global-aridity) and global potential evapotranspiration (global-PET) geospatial database. CGIAR Consortium for Spatial Information. Available from the CGIAR-CSI GeoPortal at: http://www.cgiar-csi.org. (accessed 1 September 2017)

Unger M, Leuschner C, Homeier J (2010) Variability of indices of macronutrient availability in soils at different spatial scales along an elevation transect in tropical moist forests (NE Ecuador). Plant and Soil, 336, 443-458.

This article is protected by copyright. All rights reserved. 
Vitousek PM, Chadwick OA (2013) Pedogenic thresholds and soil process domains in basaltderived soils. Ecosystems, 16, 1379-1395.

Vitousek PM, Porder S, Houlton BZ, Chadwick OA (2010) Terrestrial phosphorus limitation: mechanisms, implications, and nitrogen-phosphorus interactions. Ecological Applications, 20, 5-15.

Walker TW, Syers JK (1976) The fate of phosphorus during pedogenesis. Geoderma, 15, 119.

Wang YP, Law RM, Pak B (2010) A global model of carbon, nitrogen and phosphorus cycles for the terrestrial biosphere. Biogeosciences, 7, 2261-2282.

Yang X, Post WM (2011) Phosphorus transformations as a function of pedogenesis: A synthesis of soil phosphorus data using Hedley fractionation method. Biogeosciences, 8, 2907-2916.

Yuan Z, Jiao F, Shi X et al. (2017) Experimental and observational studies find contrasting responses of soil nutrients to climate change. eLife, $\mathbf{6}, \mathrm{e} 23255$.

Zhang C, Tian HQ, Liu JY, Wang SQ, Liu ML, Pan SF, Shi XZ (2005) Pools and distributions of soil phosphorus in China. Global Biogeochemical Cycles, 19, GB1020, doi:1010.1029/2004GB002296.

This article is protected by copyright. All rights reserved. 


\section{Figure Captions}

Fig. 1 Distribution of data locations. Soil locations contain multiple data entries.

Fig. 2 Soil $\mathrm{P}$ pools in relation to climate. Soil available $\mathrm{P}$, primary mineral $\mathrm{P}$, organic $\mathrm{P}$, secondary mineral $\mathrm{P}$, occluded $\mathrm{P}$, and total $\mathrm{P}$ in relation to mean annual temperature $(\mathrm{a}, \mathrm{d}, \mathrm{g}$, $\mathrm{j}, \mathrm{m}$, and $\mathrm{p}$, respectively) and precipitation ( $\mathrm{b}, \mathrm{e}, \mathrm{h}, \mathrm{k}, \mathrm{n}$, and $\mathrm{q}$, respectively) and aridity index (c, f, i, $1, \mathrm{o}$, and $\mathrm{r}$, respectively). ${ }^{* *} P<0.01,{ }^{* * *} P<0.001$. Solid black circles and error bars represent the mean values and standard errors, respectively, of binned soil P measures by every $2{ }^{\circ} \mathrm{C}$ for mean annual temperature (e.g. $1-3{ }^{\circ} \mathrm{C}$ ), every $200 \mathrm{~mm} \mathrm{yr}^{-1}$ for annual mean precipitation (e.g. 900-1100 $\mathrm{mm} \mathrm{yr}^{-1}$ ), and every 0.20 for aridity index (e.g. 0.90-1.10).

Fig. 3 Structural equation modelling climate effects on soil P availability. (a) A general conceptual metamodel of how climate (in blue) could affect soil P availability (light red). Climate potentially affects soil $\mathrm{P}$ availability through its effects on soil $\mathrm{P}$ forms (orange), key soil properties (grey), and some other pathways (green). Actual measured variables for each hypothetical metamodel group are in white boxes. MAT, mean annual temperature; MAP, mean annual precipitation. (b) Model on the effects of MAT and MAP on soil available P $\left(\chi^{2}=0.45, d f=2, P=0.80\right.$, RMSEA $\left.<0.001\right)$. (c) Model on the effect of aridity on soil available $\mathrm{P}\left(\chi^{2}=3.05, d f=2, P=0.22\right.$, RMSEA $\left.=0.026\right)$. Numbers on arrows are standardized path coefficients. Arrow width is proportional to the standardized coefficient. Continuous and dashed arrows indicate positive and negative relationships, respectively. Percentage near endogenous variable indicates the proportion of variance explained. Only statistically significant $(P<0.05)$ relationships were shown. The full model also included soil occluded $\mathrm{P}$ and spatial factors (the absolute value of latitude, longitude, altitude, and soil depth), as shown in Figs. S4 and S6.

Fig. 4. Standardized total effects of climate and soil properties on soil P pools. MAT, mean annual temperature; MAP, mean annual precipitation; Pava, soil available P; Porg, soil organic P; Ppri, soil primary mineral P; Psec, soil secondary mineral P; Pocc, soil occluded P.

Fig. 5. Standardized total effect of climate on the available $P$ of soils under different climate regimes (a), with different sand contents (b), and at different depths (c). Arid environment: aridity index $\leq 1.0$; non-arid environment: aridity index $>1.0$; low-sand: sand content $\leq 50 \%$; high-sand: sand content $>50 \%$; topsoils: averaged soil depth $\leq 10 \mathrm{~cm}$; subsoils: averaged soil depth $>10 \mathrm{~cm}$.

This article is protected by copyright. All rights reserved. 
Table 1. Summary of site information and selected climate and soil properties.

\begin{tabular}{|c|c|c|c|c|c|c|}
\hline Variables & $\mathrm{N}$ & Mean & Median & SD & Range & Skewness \\
\hline Latitude $\left(^{\circ}\right)$ & 758 & 18.2 & 20.7 & 26.3 & $-43.3-69.4$ & -0.4 \\
\hline Longitude $\left({ }^{\circ}\right)$ & 758 & 4.5 & -39.6 & 88.4 & $-119.8-171.6$ & 0.3 \\
\hline Altitude (m) & 755 & 931 & 646 & 942 & $11-4235$ & 1.5 \\
\hline Mean annual temperature $\left({ }^{\circ} \mathrm{C}\right)$ & 759 & 14.5 & 14.4 & 9.6 & $-5-29$ & -0.2 \\
\hline Mean annual precipitation $\left(\mathrm{mm} \mathrm{yr}^{-1}\right)$ & 759 & 1626 & 1348 & 1162 & $31-6000$ & 0.8 \\
\hline Aridity index & 758 & 1.34 & 1.10 & 0.92 & $0.03-3.92$ & 1.0 \\
\hline Averaged soil depth (cm) & 684 & 18.3 & 10.0 & 31.1 & $1-459$ & 7.4 \\
\hline Soil sand content $(\%)$ & 332 & 47.1 & 48.8 & 28.1 & $1.6-98.2$ & 0.0 \\
\hline Soil $\mathrm{pH}$ in water & 578 & 5.6 & 5.2 & 1.4 & $3.4-9.5$ & 0.6 \\
\hline Soil organic C $(\%)$ & 628 & 4.4 & 2.1 & 6.4 & $0.02-49$ & 3.3 \\
\hline Soil total N (\%) & 461 & 0.3 & 0.2 & 0.3 & $0.01-2.68$ & 2.8 \\
\hline Soil total $\mathrm{P}\left(\mathrm{mg} \mathrm{kg}^{-1}\right)$ & 742 & 448.8 & 359.0 & 351.7 & $4.8-2157$ & 1.6 \\
\hline Soil available $\mathrm{P}\left(\mathrm{mg} \mathrm{kg}^{-1}\right)$ & 691 & 24.3 & 13.0 & 34.2 & $0.1-266$ & 3.6 \\
\hline Soil organic $\mathrm{P}\left(\mathrm{mg} \mathrm{kg}^{-1}\right)$ & 625 & 125.9 & 64.1 & 155.3 & $4.4-818$ & 2.0 \\
\hline Soil primary mineral $\mathrm{P}\left(\mathrm{mg} \mathrm{kg}^{-1}\right)$ & 661 & 92.1 & 25.0 & 158.7 & $0.1-1031.4$ & 3.2 \\
\hline Soil secondary mineral $\mathrm{P}\left(\mathrm{mg} \mathrm{kg}^{-1}\right)$ & 697 & 40.3 & 24.9 & 47.8 & $0.6-322$ & 2.9 \\
\hline Soil occluded P $\left(\mathrm{mg} \mathrm{kg}^{-1}\right)$ & 707 & 175.2 & 130.3 & 164.6 & $0.3-998.1$ & 2.3 \\
\hline
\end{tabular}

This article is protected by copyright. All rights reserved. 
Table 2. Relative influences of climate, vegetation, soil, and parent material properties on soil P pools quantified by boosted regression tree (BRT) analysis. Predictor's relative influence $(\%)$ represents the relative influences of ecosystem properties on soil $\mathrm{P}$ pool in each BRT model.

Predictor's relative influence

\begin{tabular}{lllll}
\hline Soil & Soil & Soil primary & Soil secondary & Soil
\end{tabular}

available $\mathrm{P}$ organic $\mathrm{P}$ mineral $\mathrm{P}$ mineral $\mathrm{P} \quad$ occluded $\mathrm{P}$

\begin{tabular}{llllll}
\hline Mean annual temperature & 16.5 & 8.3 & 29.7 & 11.1 & 10.1 \\
Mean annual precipitation & 16.1 & 6.2 & 4.3 & 7.4 & 11.6 \\
Vegetation type & 2.0 & 0.6 & 2.7 & 4.0 & 1.1 \\
Soil type & 13.3 & 9.3 & 25.8 & 15.9 & 19.3 \\
Soil organic C & 22.5 & 53.3 & 6.1 & 15.2 & 18.2 \\
Soil pH & 11.2 & 12.7 & 23.8 & 22.6 & 17.0 \\
Soil sand content & 3.9 & 4.8 & 3.8 & 13.1 & 14.5 \\
Parent material type & 14.6 & 4.9 & 3.8 & 10.8 & 8.2 \\
$N$ & 691 & 625 & 661 & 697 & 707 \\
$R^{2}$ & 0.82 & 0.89 & 0.91 & 0.83 & 0.84 \\
$P$ & $<0.001$ & $<0.001$ & $<0.001$ & $<0.001$ & $<0.001$
\end{tabular}

This article is protected by copyright. All rights reserved. 


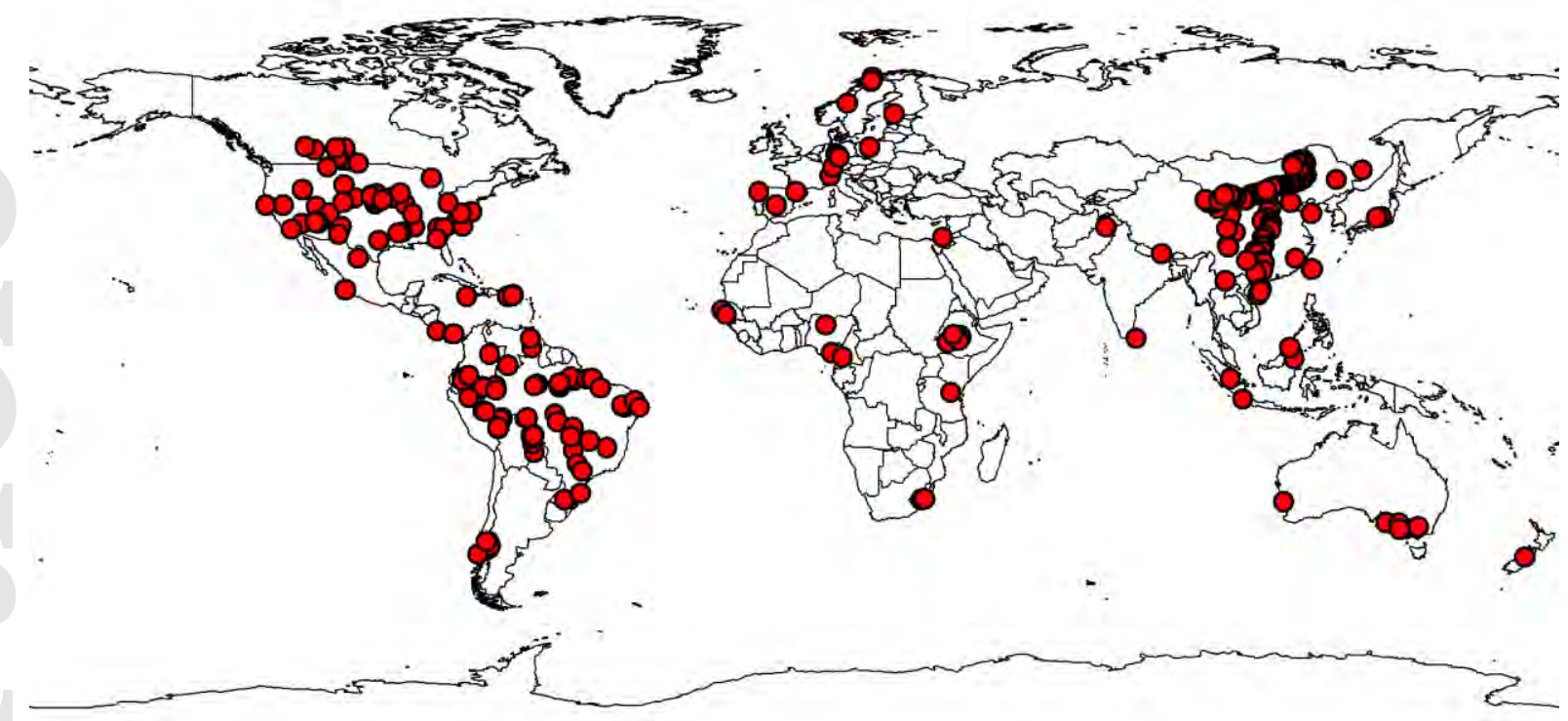

This article is protected by copyright. All rights reserved. 


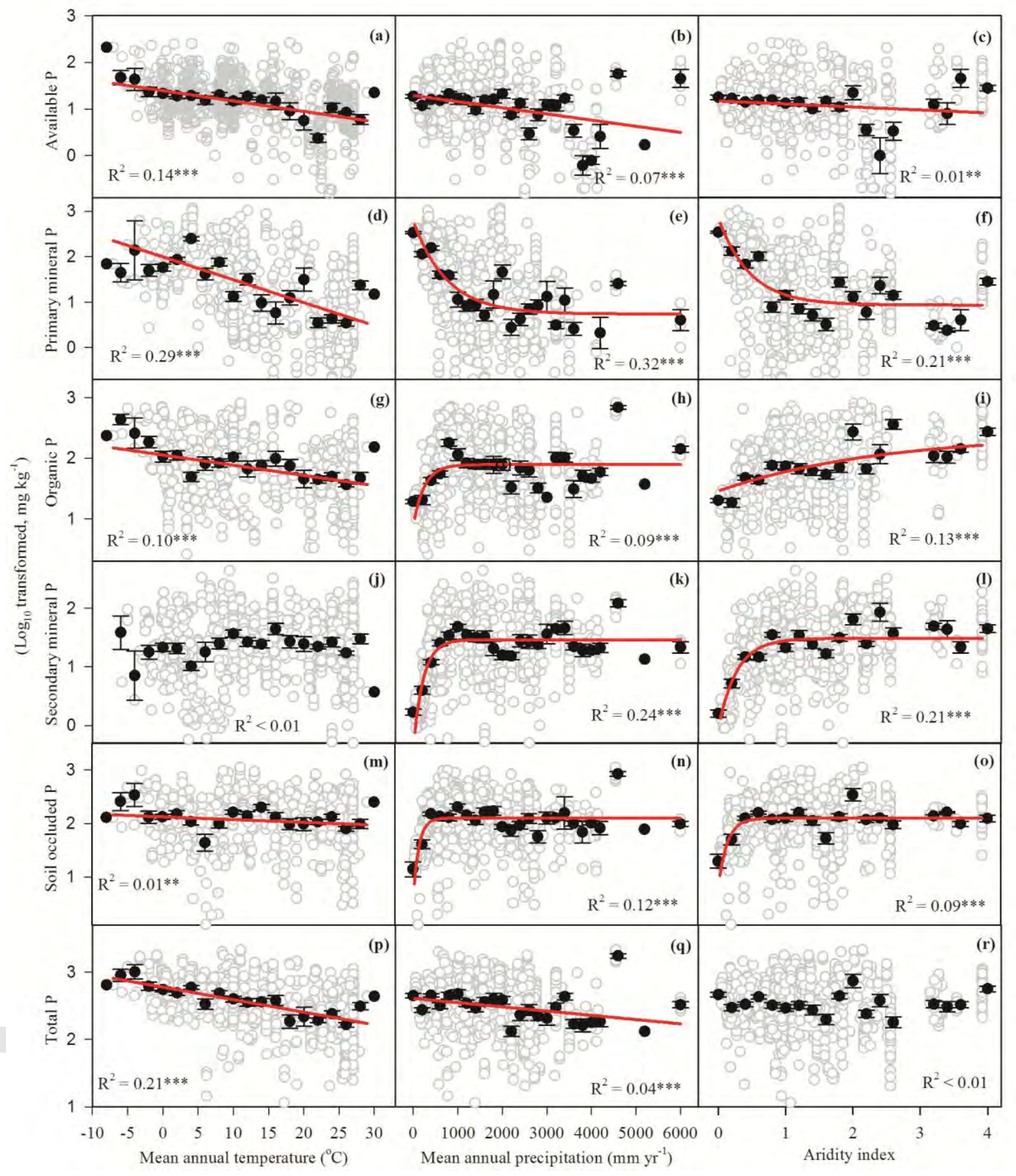

This article is protected by copyright. All rights reserved. 

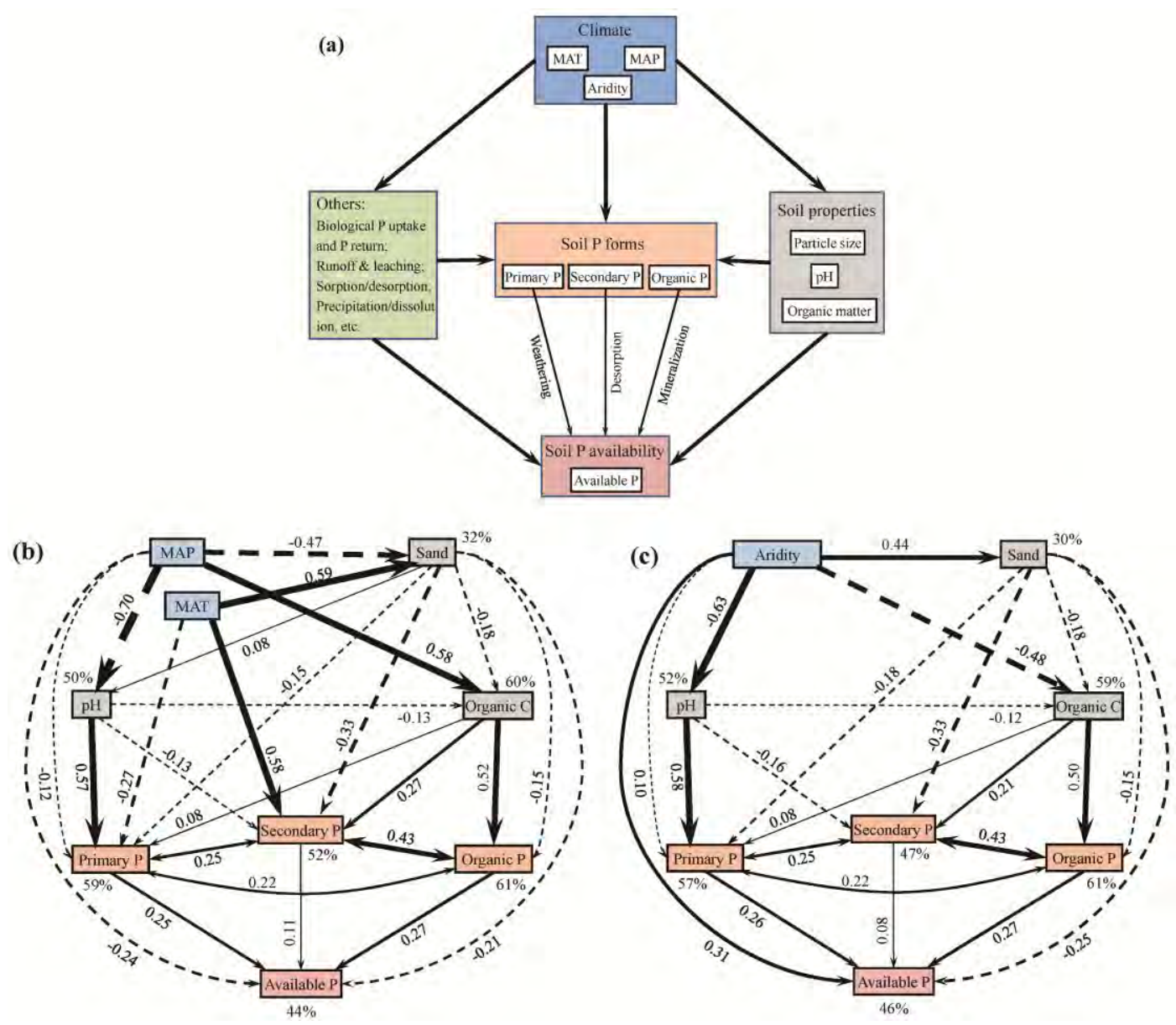

This article is protected by copyright. All rights reserved. 

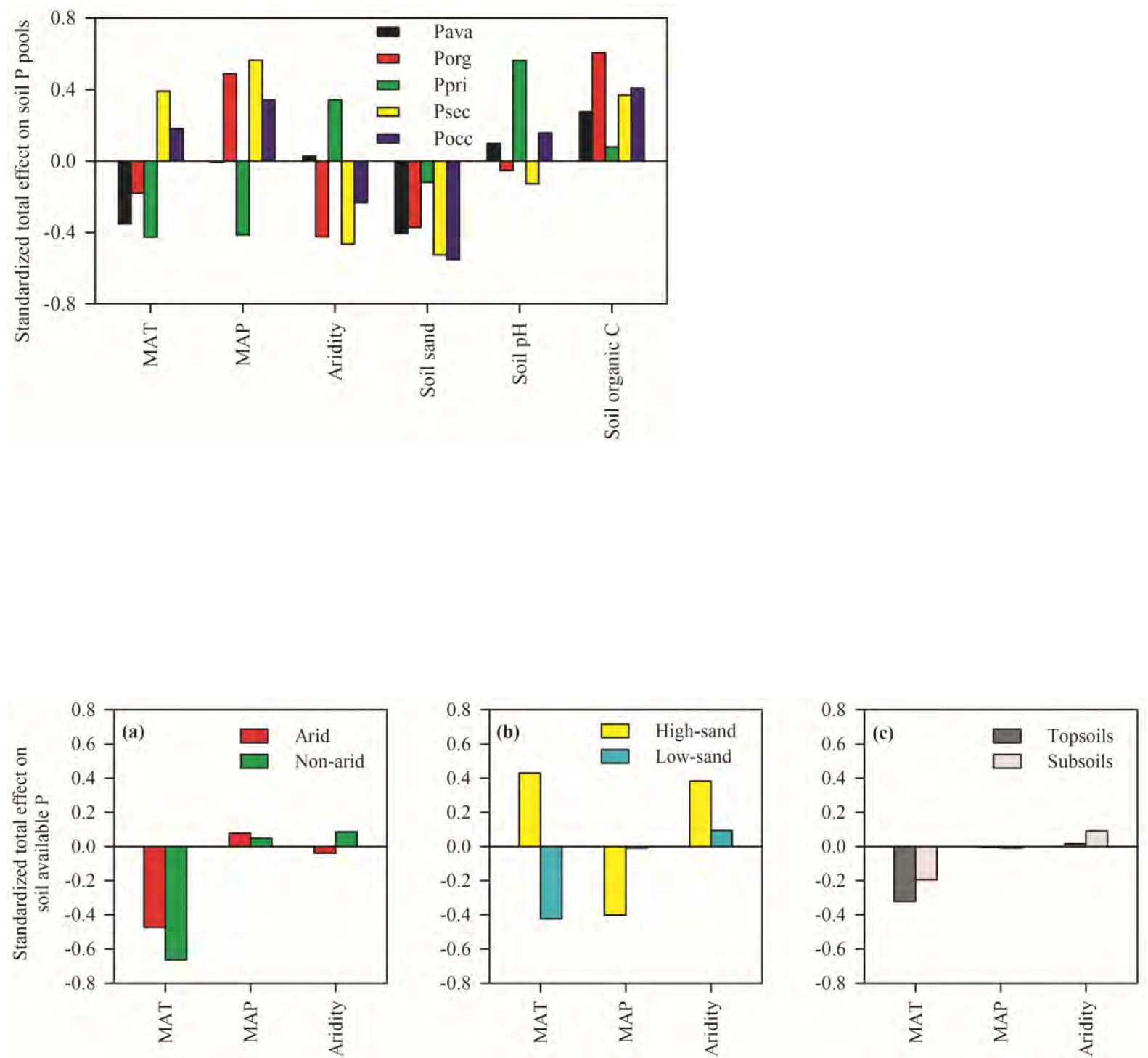

This article is protected by copyright. All rights reserved. 